\title{
WYCHOWANIE RELIGIJNE W BIOGRAFIACH MŁODZIEŻY \\ ZAGROŻONEJ NIEDOSTOSOWANIEM SPOŁECZNYM - PREZENTACJA WYNIKÓW BADAŃ ${ }^{* *}$
}

Streszczenie: Poniższa praca jest prezentacją wyników badań zrealizowanych na potrzeby pracy magisterskiej. Przedmiotem badania było wychowanie religijne młodzieży zagrożonej niedostosowaniem społecznym, a proces badawczy poświęcony był diagnozie stanu wychowania religijnego oraz opisowi przebiegu tego wychowania. Badanie było przeprowadzone w oparciu o metodę biograficzną z wykorzystaniem techniki wywiadu swobodnego. Z przeprowadzonych badań wynika, że wychowanie religijne badanej młodzieży jest ograniczone $\mathrm{w}$ swoich przejawach oraz wystąpiło głównie w okresie edukacji początkowej.

Słowa kluczowe: wychowanie religijne, wychowanie w nauczaniu Kościoła Katolickiego, religijność, młodzież zagrożona niedostosowaniem społecznym, resocjalizacja.

\section{Wprowadzenie}

We współczesnym dyskursie coraz częściej mówi się o religijności człowieka (np. Heland-Kurzak; Szydłowski), a także o religijnych aspektach terapeutycznych w kontekście resocjalizacji (np. Stańkowski; Kustra; Pol). Dokonując kwerendy

* Mgr Piotr Okraska, absolwent kierunku pedagogika o specjalności pedagogika resocjalizacyjna na Wydziale Nauk o Wychowaniu Uniwersytetu Łódzkiego, Uniwersytet Łódzki; adres e-mail: piotrek.okraska8@gmail.com.

** Artykuł powstał na podstawie badań przeprowadzonych do niepublikowanej pracy magisterskiej pt. „Wychowanie religijne w biografiach młodzieży zagrożonej niedostosowaniem społecznym”, która została napisana pod kierunkiem dr hab. Anety Bołdyrew, prof. UŁ na Wydziale Nauk o Wychowaniu w Uniwersytecie Łódzkim i obroniona w 2020 roku. 
literatury pedagogicznej oraz psychologicznej, znajdziemy małą liczbę publikacji poświęconych opisowi przebiegu wychowania religijnego młodzieży niedostosowanej społecznie, a tym bardziej dotyczących młodzieży zagrożonej niedostosowaniem społecznym. Postanowiłem opisać ten mało poznany aspekt wychowania, ponieważ byłem ciekaw, jak kształtuje się życie religijne wśród młodzieży z tej grupy społecznej i czy wykształcona religijność daje szansę na jej wykorzystanie $\mathrm{w}$ procesie resocjalizacji.

\section{Wychowanie religijne}

Wychowanie religijne jest jednym $\mathrm{z}$ aspektów procesu wychowawczego człowieka. Pedagodzy religii wielorako wyjaśniają, czym ono jest ${ }^{1}$. W szerokim znaczeniu wychowanie religijne rozumiane jest jako kształtowanie światopoglądu człowieka, uwzględniające i podkreślające aspekty religijne (Charchut 2015, s. 173-179). Można zatem powiedzieć, że wychowanie religijne jest to „system wychowania oparty na podporządkowaniu działalności edukacyjnej założeniom jakiejś religii” (Okoń 2001, s. 448), w którym za cel i sens wychowania uznaje się wspomaganie jednostki w stawaniu się dojrzalszą, twórczą oraz w byciu lepszym człowiekiem (Słotwińska 2016, s. 61). Anna Królikowska w rozdziale swojej książki, w której opisuje, czym jest wychowanie religijne, stwierdza, że trudne jest jednoznaczne zdefiniowanie tej kategorii wychowania ze względu na wielość systemów, kierunków i prądów wychowania obecnych w społecznościach religijnych. Jednocześnie pisze, że najczęściej wychowanie religijne sprowadza się do wszelkich czynności prowadzących do zgłębienia więzi jednostki z Bogiem (Królikowska 2008, s. 90-95).

We współczesnym dyskursie naukowym, związanym $\mathrm{z}$ badaniami nad wychowaniem religijnym, możemy spotkać się z różnymi kierunkami działań. $\mathrm{Na}$ przykład Małgorzata Czekaj przeprowadziła badania nt. życia religijnego rodziny polskiej oraz opisała wychowanie religijne w środowisku rodzinnym (Czekaj 2015). A. Królikowska zrealizowała badania zorientowane na zależność pomiędzy diagnozą stanu świadomości religijnej młodzieży, opartej na systemach pojęć religijnych, a związkiem z dojrzałością wiary (Królikowska 2008). Natomiast K. Heland-Kurzak zajęła się tematyką dziecięcej kreacji obrazu Boga i religijności (2021).

Przeprowadzone przeze mnie badania dotyczyły przede wszystkim młodzieży wychowywanej w kulturze polskiej, dla której dominującym wyznaniem wiary jest katolicyzm. Dla lepszego zgłębienia badanego zagadnienia przybliżę rozumienie wychowania religijnego w nauczaniu Kościoła Katolickiego.

1 Zdefiniowaniem i opisem wychowania religijnego zajęli się m.in. ks. Janusz Tarnowski (Śliwerski 2015, s. 69-82), Anna Królikowska (2008, s. 87-107) oraz Cyprian Rogowski (2012). 


\section{Wychowanie religijne w nauczaniu Kościoła katolickiego}

Podstawą współczesnego rozumienia wychowania religijnego w Kościele katolickim są: Encyklika „Divini Illius Magistri - o chrześcijańskim wychowaniu młodzieży papieża Piusa XI oraz Deklaracja Soboru Watykańskiego II o wychowaniu chrześcijańskim. Pius XI w swojej encyklice określa wychowanie religijne jako „sztukę wychowania zmierzającą do takiego urabiania człowieka, do jakiego on musi dojść, żeby tu osiągnął cel, przeznaczony mu przez Stwórcę" (Pius XI 1929). Według niego za prawidłowy przebieg procesu wychowania odpowiedzialne są trzy środowiska: rodzina, państwo oraz Kościól, które wzajemnie się dopełniają. W encyklice papież za cel wychowania religijnego przyjął współpracę człowieka z łaską Bożą, co stwarza możliwość, aby stać się autentycznym, a zarazem doskonałym chrześcijaninem. Kolejnymi prezentowanymi celami są zbawienie oraz przynoszenie jak największych korzyści i pożytków dla społeczeństwa. Jednocześnie Pius XI w swojej wizji wychowawczej odwołuje się do wychowania klasycznego, przy jednoczesnym negatywnym nastawieniu do ówcześnie nowo powstających nurtów wychowawczych, w których upatruje zagrożenie (Pius XI 1929).

Drugim ważnym dokumentem jest Deklaracja o wychowaniu chrześcijańskim II Soboru Watykańskiego, która umocniła ważność poglądów wychowawczych przedstawionych przez papieża Piusa XI w jego encyklice. Jednocześnie Sobór potwierdził prawo każdego chrześcijanina do wychowania w swojej wierze, aby coraz bardziej pogłębiać wyznawany depozyt wiary (Paweł VI 1965).

Ważny wkład w zrozumienie chrześcijańskiego wychowania religijnego miało trzech papieży: św. Jan Paweł II, Benedykt XVI oraz Franciszek.

Święty Jan Paweł II wychowanie religijne zdefiniował jako wspieranie rozwoju człowieka w kontekście wszelkich aspektów życia, lecz za najważniejszy aspekt wychowania uznał przygotowanie młodego człowieka na spotkanie z Bogiem, co wyznacza jednostce cel życia, jakim jest zbawienie (Mastalski 2012). Wychowanie Papieża Polaka opiera się na sześciu filarach:

1. Chrystocentryzmie - Jezus Chrystus jest ideałem wychowawczym, do którego mamy zmierzać wychowując dzieci;

2. Spójnej, pełnej odniesień do zbawienia teologii - celem wychowania jest doprowadzenie do zbawienia człowieka;

3. Chrześcijańskiej aksjologii - kierowanie się w życiu chrześcijańskimi wartościami, które łączą się z ludzkim sumieniem, wskazującym prawidłową drogę prowadzącą do zbawienia;

4. Środowisku wychowawczym - w procesie wychowania aktywny udział biorą rodzina, szkoła, rówieśnicy oraz Kościół;

5. Samowychowaniu - wraz z uzyskaniem dojrzałości człowiek zaczyna samemu wychowywać się poprzez kontakt ze społeczeństwem, zgodnie z wartościami, które zostały mu przekazane w dzieciństwie; 
6. Pedagogice zasad - proces wychowawczy powinien opierać się na następujących zasadach: wychowaniu do miłości, wychowaniu do poszanowania godności ludzkiej, wychowaniu do twórczej pracy, wychowaniu, w którym Mistrzem jest Chrystus, wychowaniu do wartości, wychowaniu do prawidłowej samooceny, wychowaniu w konsekwencji i prawdzie (Stańkowski 2015; Mastalski 2012).

Również następcy św. Jana Pawła II podjęli tematykę wychowania w swoim nauczaniu. Benedykt XVI, mówiąc o współczesnym wychowaniu i jego trudach, nawiązywał do tego, że jest ono nierozłączne $\mathrm{z}$ ewangelizacją młodych ludzi. Jednocześnie podkreślał, że młodych należy otwierać na transcendencję i otaczających ich ludzi. Wychowanie ma prowadzić do poczucia wolności i zrozumienia siebie przy jednoczesnym naśladowaniu Pana (Stańkowski 2015; Mastalski 2012)2 ${ }^{2}$.

Obecnie urzędujący papież również wypowiedział się o współczesnym wychowaniu chrześcijańskim. Franciszek proces ten definiuje jako dialog pomiędzy dwojgiem ludzi, dzięki któremu wzajemne się poznajemy, a także kładzie nacisk na kształtowanie u dziecka odpowiedzialności i świadomości czynów oraz uwrażliwia na współczesne trudności, z jakimi boryka się obecnie rodzina. W jego nauczaniu nie brakuje również otwarcia młodych pokoleń na miłość do Chrystusa (Bergolio - Franciszek 2013; Franciszek 2016).

Katolicka wizja wychowawcza oparta na Piśmie Świętym i nauczaniu papieskim ewoluuje. Papieże XX wieku w swoich postulatach wychowawczych kładli nacisk zarówno na wskazanie osób odpowiedzialnych za wychowanie, jak i na przysługujące im prawa, poprzez ukazanie, w jaki sposób należy wychowywać dzieci. Natomiast w XXI wieku skupili się oni na uwrażliwieniu rozterek współczesnej rodziny. Warto podkreślić, że zaobserwowana ewolucja łączy się z zachodzącymi zmianami w życiu społecznym, politycznym, gospodarczym, jak i ideologicznym.

\section{Zagrożenie niedostosowaniem społecznym}

W swojej pracy badawczej skupiłem się na osobach zagrożonych niedostosowaniem społecznym, którym w literaturze przedmiotu poświęca się mało miejsca. Kim jednak są te osoby? Można przyjąć, że zagrożenie niedostosowaniem społecznym stanowi pewien etap w kształtowaniu się w jednostce niedostosowania społecznego, który polega na pojawianiu się nowych cech niedostosowania oraz nasileniu dotychczas posiadanych. Beata Matusek zagrożenie niedostosowaniem społecznym definiuje w sposób następujący: „postawy i zachowania odbiegające od przyjętej normy, ale o mniejszym nasileniu i mniejszej częstotliwości niż w przypadku ucznia niedostosowanego społecznie" (Matusek 2015, s. 146 - 147). Do oceny

2 Dostepny na: https://opoka.org.pl/biblioteka/W/WP/benedykt_xvi/listy/wychowanie_21012008. html (dostęp 19.03.2019). 
nasilenia częstotliwości wystąpienia cech niedostosowania społecznego przyda się tabela Bożeny Krupy.

Tabela 1. Obszary i przejawy niedostosowania

\begin{tabular}{|l|l|}
\hline \multicolumn{1}{|c|}{$\begin{array}{c}\text { Obszar/poziom } \\
\text { niedostosowania }\end{array}$} & \multicolumn{1}{|c|}{ Przejawy niedostosowania/demoralizacji } \\
\hline Niski & $\begin{array}{l}\text { Wagary, lekceważenie obowiązku szkolnego, agresja werbalna, poczucie } \\
\text { odtrącenia, frustracja, nieadekwatne reakcje, impulsywność, brak } \\
\text { koncentracji, „wołanie o pomoc”. }\end{array}$ \\
\hline Średni & $\begin{array}{l}\text { Jak wyżej, i dodatkowo: kradzieże, agresja fizyczna, arogancja, } \\
\text { wulgaryzm, papierosy, alkohol, ucieczki z domu, autoagresja } \\
\text { (okaleczenia), kontakty z subkulturą, bunt wobec autorytetów, próby } \\
\text { samobójcze, wyzywające zachowania seksualne, odurzenia środkami } \\
\text { psychoaktywnymi. }\end{array}$ \\
\hline Wysoki & $\begin{array}{l}\text { Jak wyżej, i rozboje, napady, włamania, styl życia i „normy” grupy } \\
\text { przestępczej, uzależnienie, np. od narkotyków, ucieczki z placówek, } \\
\text { negacja norm moralnych, prawnych, neutralnych, wandalizm }\end{array}$ \\
\hline
\end{tabular}

Źródło: Krupa B. (2011). Doświadczenia życiowe młodzieży z okresu wczesnego dzieciństwa i ich związek z niedostosowaniem społecznym. Łódź: Wydawnictwo WSEZiNS, s. 25.

W pracy przyjąłem następującą definicję zagrożenia niedostosowaniem społecznym uwzględniającą treść tabeli pierwszej oraz fakt, że uwzględnia dzieci pochodzące z rodzin o niekorzystnych warunkach środowiskowych, co nie sprzyja ich prawidłowemu rozwojowi psychospołecznemu (Pytka 2005).

\section{Metodyczne podstawy badań własnych}

Przedmiotem przeprowadzonych badań było wychowanie religijne młodzieży zagrożonej niedostosowaniem społecznym. Realizując projekt badawczy, zostały przyjęte następujące cele badawcze:

- opisanie religijności młodzieży zagrożonej niedostosowaniem społecznym;

- opisanie przejawów wychowania religijnego młodzieży zagrożonej niedostosowaniem społecznym;

- opisanie religii jako wsparcia dla procesu wychowawczego.

Badaniom towarzyszył następujący główny problem badawczy: jak przejawiało się wychowanie religijne w biografiach małoletnich wychowanków zagrożonych niedostosowaniem społecznym?

$\mathrm{Z}$ powyższego problemu głównego wyodrębniono następujące problemy szczegółowe:

1. Jaki stosunek do religii oraz jaki typ religijności reprezentuje młodzież zagrożona niedostosowaniem społecznym?;

2. Jak przebiegało wychowanie religijne młodzieży zagrożonej niedostosowaniem społecznym w ich biografiach?; 
3. W kim młodzież, zagrożona niedostosowaniem społecznym, widzi wzorce życia religijnego oraz autorytety moralne?;

4. Czy i w jakim stopniu wiedza religijna i moralna posiadana przez młodzież zagrożoną niedostosowaniem społecznym jest zależna od klimatu religijnego, jaki panował w domu rodzinnym?;

5. W jakim zakresie religia pomaga młodzieży zagrożonej niedostosowaniem społecznym w trudach życia dnia codziennego?;

6. Czy i w jaki sposób religia wspiera proces socjalizacji i resocjalizacji młodzieży zagrożonej niedostosowaniem społecznym?

Zrezygnowałem z postawienia hipotez badawczych, ponieważ nie wprowadzają one niczego nowego do pracy, gdyż wyniki badań dają odpowiedź na problemy badawcze, a nie na hipotezy (Urbaniak-Zając 2009).

Badania realizowane były według schematu badań jakościowych, zaś za metodę badawczą przyjęto metodę biograficzną przy zastosowaniu techniki wywiadu. Wywiad był jawny i nieustrukturyzowany. Został on zrealizowany z pięciorgiem wychowanków Młodzieżowego Ośrodka Socjoterapii. Próba badawcza była oparta na doborze nielosowym celowym (Creswell 2013; Nowak 2007; Kowalik 2001; Konecki 2000; Rubacha 2011).

\section{Prezentacja wyników badań własnych. \\ Stosunek do religii oraz typ religijności reprezentowany przez młodzież zagrożoną niedostosowaniem społecznym}

Z wypowiedzi badanej młodzieży wynika, że posiadają niewiele wspomnień i przejawów aktywności z okresu wczesnego dzieciństwa związanych z religią i religijnością. $Z$ tego okresu w opowieściach niektórych badanych wyłaniały się obrazy przygotowań świątecznych spotkań rodzinnych. Świadczyć o tym może następujący fragment wywiadu: „Badany: Najczęściej mama. Badacz: Czyli wprowadzała Cię w te święta - w ten przekaz religijny, duchowy? Badany: (potwierdzające kiwnięcie głową przez badanego). Badacz: Czy to było, zanim poszłaś do szkoły, w klasach I-III i potem w następnych klasach? Zawsze tak było? Badany: Jak byłam mniej więcej w przedszkolu. Badacz: Jak byłaś w przedszkolu, to mama opowiadała, na czym polegają różne święta, jaki to jest symbol, tak? Badany: (potwierdzające kiwnięcie głową przez badanego). Badacz: Potem już tego nie było? Badany: (potwierdzające kiwnięcie głową przez badanego)" [fragment wywiadu 4].

Wzrost przejawów aktywności życia religijnego badanej młodzieży przy jednoczesnym osiągnięciu szczytu aktywności religijnej występuje w okresie edukacji początkowej w szkole podstawowej. Z narracji badanych wynika, że do danego stanu rzeczy przyczyniły się przygotowania do Pierwszej Komunii Świętej, które to głównie ograniczały się do zakupów stroju komunijnego i dewocjonaliów niezbędnych do przyjęcia tego sakramentu. „Badacz: Czy rodzice wspierali Cię w przygotowaniach do Pierwszej Komunii Świętej? Badany: No, wspierali. Co weekend 
gdzieś byłem z nimi wybrać jakieś rzeczy do Komunii, no na przykład garnitur, i to wszystko. Badacz: A czy w tym też był aspekt rozwoju religijnego? Ktoś Ci pomagał rozwiązywać problemy religijne? Badany: Nie. Yyy mama trochę pomagała nauczyć się tej formułki do spowiedzi" [fragment wywiadu 2].

Poza materialnymi przygotowaniami komunijnymi w tym czasie wyraźnie zarysowały się we wspomnieniach badanych szkolne oraz domowe przygotowania do Pierwszej Komunii Świętej, związane z nauką treści modlitw oraz z przebiegiem ceremonii. Jest to jedyny okres, w którym badani adolescenci wykazywali regularną aktywność religijną na Mszach Świętych, nabożeństwach, rekolekcjach, katechezie szkolnej oraz na wspólnej nauce $\mathrm{w}$ domu $\mathrm{z}$ rodzicami. Z zebranego materiału empirycznego wynikły dwie główne przyczyny przyjęcia Pierwszej Komunii Świętej. Pierwszym dominującym powodem był obowiązujący zwyczaj społeczno-kulturowy. Rodzice badanych, dając prawo wyboru przystąpienia do Komunii, podkreślali fakt, że wypada ją przyjąć, gdyż jest to ważny zwyczaj. Drugą motywacją był aspekt materialny, a dokładniej uzyskanie prezentów. Część badanych, podejmując decyzję wraz z rodzicami o przyjęciu po raz pierwszy tego sakramentu, zdecydowali się na to wyłącznie z uwagi na możliwość uzyskania prezentów z tejże okazji.

Okres młodzieńczy charakteryzuje się spadkiem aktywności religijnej. Coraz rzadziej badani uczęszczali na Mszę św. Lekcje religii przestają pełnić funkcję dydaktyczną, a jedynie ograniczają się do spotkań towarzyskich, gdzie można spokojnie porozmawiać ze znajomymi lub też pozwalają uniknąć uczęszczania na świetlicę szkolną. Tak samo jest $\mathrm{z}$ rekolekcjami, kiedy motywacją do udziału w nich jest uniknięcie lekcji szkolnych przy jednoczesnym uzyskaniu dnia wolnego, podczas którego można porozmawiać z bliskimi znajomymi. „Po prostu, jak widziałem, ile osób zostaje w szkole, to nie chciałem samemu siedzieć. Może z dwie lub trzy osoby zostawały w szkole, a reszta szła na rekolekcje" [fragment wywiadu 2]. Badani deklarowali, że katecheza szkolna i rekolekcje w tym czasie nie wpłynęły na rozwój ich duchowości, a wszelka podejmowana działalność ograniczała się do jak najprostszego zaliczenia przedmiotu i poświęcenia więcej czasu znajomym. Ciekawym faktem było to, że część badanych pomimo ambiwalentnego stosunku do katechez odczuwała potrzebę uzyskania wsparcia religijno-duchowego od swoich katechetów.

Okres adolescencji dla badanych to czas aktywności w różnych stowarzyszeniach religijnych lub organizacjach, które odwołują się do wartości religijnych, np. grupy ministranckie, chór kościelny, harcerstwo oraz udział w jednorazowych akcjach charytatywnych organizowanych na terenie parafii. Dominującymi motywacjami do podjęcia tych aktywności przez badanych były korzyści zewnętrzne, tj. organizacja czasu wolnego, spotkanie ze znajomymi, drobne korzyści materialne pod postacią uzyskiwania słodyczy oraz zdobycie lepszej oceny z religii. Jedna z osób badanych podjęła się swojej działalności z powodu chęci niesienia pomocy innym. Żaden $\mathrm{z}$ badanych adolescentów nie podjął aktywności $\mathrm{w}$ wyżej wymienionych 
organizacjach z przyczyn religijnych. Respondenci stwierdzili, że powyższa działalność nie przyczyniła się do wzrostu ich religijności.

Kolejnym badanym etapem religijności wśród adolescentów był czas związany z bierzmowaniem. Wśród badanych nie było większego zainteresowania tym sakramentem. Gdy się już ono jednak pojawiało, było motywowane uzyskaniem pewnych „przywilejów” związanych z byciem osobą bierzmowaną. „Po prostu chciałabym mieć ślub kościelny i chrzestną zostać” [fragment wywiadu 5].

Badani przyznali, że największą religijność obserwowali u siebie w okresie edukacji początkowej, co z czasem zaczęło spadać. W narracjach można było wyodrębnić treści, w których respondenci mówili, że jeśli poprawią swoją relację z Bogiem, to Ten zacznie ich widzieć i będzie im pomagał. Jednakże brak reakcji na modlitwy badanych powodował u nich poczucie odrzucenia ze strony Boga i porzucenie praktyki religijnej.

Respondenci pomimo niskiego poziomu religijności oraz wiedzy religijnej odczuwali potrzebę relacji z Bogiem w sytuacjach trudnych. Wsparcie to było rozumiane jako Boska interwencja, która od razu rozwiązuje napotkany problem. „Badacz: Czy kiedykolwiek w trudnych sytuacjach problemowych nie wiedziałaś, jak postąpić i próbowałaś odwołać się do religii? Badany: Tak. Badacz: Kiedy to było? Badany: Jak się cięłam. Badacz: Co wtedy ta religia Ci dawała? Badany: No mówiłam do tego Pana Boga, że co dalej robić i w ogóle (...). Badacz: Nie czułaś tego sprzeciwu, że religia nie pozwala mi tego robić, a jednak to robię? Badany: Nie czułam tego. Badacz: Nie czułaś tego? Badany: Bo miał mnie w tyłku. Badacz: Czyli tnę się, Bóg mi nie daje znaku, że mam tego nie robić, czyli ma mnie gdzieś. A jak byś miała olśnienie czy jakiś znak, to przestałabyś to robić? Badany: Tak. Badacz: Miałaś nadzieję, że zainterweniuje? Badany: Uhum. Badacz: I to był moment, jak przestałaś wierzyć? Badany: Tak" [fragment wywiadu 5]. Ten krótki fragment dobrze ukazuje, że młodzież zagrożona niedostosowaniem społecznym, pomimo niskiej religijność, odczuwa potrzebę pomocy ze strony Boga, gdzie ta pomoc może zostać ekstremalnie wystawiona na próbę.

Podsumowując, badana młodzież, zagrożona niedostosowaniem społecznym, reprezentuje obojętny stosunek do religii, a praktyka religijna podporządkowana jest zwyczajom społecznym oraz korzyściom materialnym. Badana młodzież reprezentuje wszelkie znamiona religijności zewnętrznej przy jednoczesnym niskim poziomie wiedzy religijnej. Oceniając rozwój religijności respondentów, przebiega on zgodnie z założeniami psychologii religii do okresu edukacji wczesnoszkolnej. W wyniku braku odpowiedniej stymulacji wychowawczej zorientowanej na rozwój religijny badani nie rozwijają się religijnie. Ich poziom religijności w okresie adolescencji zatrzymał się na etapie religijności dziecięcej typu magicznego ${ }^{3}$. Opisane

3 Religijność typu magicznego - etap w rozwoju religijności człowieka występujący wieku od ok. 4 roku życia do ok. 7 roku życia. Charakteryzuje się nieświadomością grzechu, postrzeganiem Boga jako czarodzieja, który spełnia marzenia przedstawione w modlitwie. Dzieci na tym 
przejawy życia religijnego oraz sposób myślenia badanych o religii dobrze wpisują się w nowe zjawisko, jakim jest Moralistyczny Deizm Terapeutyczny ${ }^{4}$.

\section{Przebieg wychowania religijnego młodzieży zagrożonej niedostosowaniem społecznym}

Człowiek doświadcza pierwszych praktyk religijnych w okresie dziecięcym. Okres ten jest bardzo ważny pod względem tworzenia pierwszych wspomnień religijnych przez jednostkę (Królikowska 2008, s. 107). Czas poświęcony na wychowanie religijne respondentów nie został prawidłowo wykorzystany przez wychowawców. Wśród wszystkich badanych tylko jedna osoba wspomniała, że w okresie przedszkolnym opowiadano jej o znaczeniu celebrowanych w domu świąt religijnych. Reszta badanych nie deklarowała żadnych wspomnień religijnych z tego okresu. Po dopytaniu się, czemu rodzice w okresie przedszkolnym nie chodzili z nimi np. na Mszę, stwierdzili, że byli na to za młodzi. „W ogóle nie chodziłem. Jeszcze przed klasami I-III nie chodziłem, bo do przedszkola chodziłem" [fragment wywiadu 2].

Najintensywniejszym etapem wychowania religijnego jest okres edukacji początkowej w szkole podstawowej. Łączy się on z przygotowaniami do Pierwszej Komunii Świętej. Zarówno rodzice, jak i katecheci reprezentują wtedy najintensywniejszą działalność wychowawczą zorientowaną na religię. To właśnie w okresie nauczania początkowego zaczyna się regularna i intensywna praktyka religijna - Msza Święta, katecheza szkolna, rekolekcje oraz nauka modlitw i przygotowanie do przyjęcia sakramentu wraz z zaangażowaniem się w to rodziców. Domowe przygotowania były zorientowane bardziej na prawidłowym przebiegu oraz wartościach estetycznych, a niżeli na skupieniu się na treściach teologicznych wynikających z przyjęcia sakramentu Pierwszej Komunii Świętej. Respondenci jednoznacznie stwierdzili, że uroczystość ta ma charakter tradycji kulturowej, a nie duchowy. Trzeba również podkreślić, że jest to okres najlepszy na katechizację młodzieży. Z narracji respondentów wynika, że w klasach I-III SP byli oni najbardziej zainteresowani treściami religijnymi oraz z chęcią oznajmiali swoje rozterki religijne katechetom. Jednocześnie katecheta cieszył się największym poważaniem wśród badanych.

etapie są bardzo podatne na przekazywane im treści religijne oraz chętnie i z zaangażowaniem uczestniczą w prostych praktykach religijnych, jak np. modlitwa. Dzieci w tym wieku często wykorzystują motywy religijne w swoich zabawach (Kuczkowski 1999, s. 67-71; Heland-Kurzak 2021, s. 41).

4 Moralistyczny Deizm Terapeutyczny (MDT) - polega on na tym, że to człowiek, a nie Bóg, stawiany jest na pierwszym miejscu. Rolą Boga jest zaspakajanie wszelkich potrzeb człowieka. W MDT Bóg stworzył świat i obserwuje ludzi, którzy mają być dobrzy. Celem życia człowieka jest bycie szczęśliwym. Jednocześnie Bóg ma interweniować w każdej potrzebie człowieka, na jego wezwanie, a ten jako dobry, zgodnie ze swoim przekonaniem, na pewno trafi do nieba (Skrzypczak 2020, s. 277). 
Na następnych etapach edukacji szkolnej poziom intensywności życia religijnego i wychowania religijnego spadł. Rodzice w minimalnym stopniu skupili się na religijnych aspektach wychowania. Katecheza i rekolekcje były wyłącznie miejscem spotkań towarzyskich oraz uniknięciem innych zajęć dydaktycznych $\mathrm{w}$ szkole. Intensywna rola katechety w wychowaniu religijnym respondentów drastycznie spadła - przestał on być autorytetem. Na tym etapie młodzież zatraciła chęć poszukiwania odpowiedzi na nurtujące ich treści religijne, a uzyskana dotychczas wiedza religijna był im wystarczająca. $\mathrm{W}$ ocenie badanych sporadyczne podejmowanie aktywności $\mathrm{w}$ organizacjach religijnych lub odwołujących się do wartości religijnych (ministranci, chór kościelny, harcerstwo, akcje charytatywne organizowane w parafii) przyczyniło się do subiektywnego wzrostu religijności oraz do wzrostu zainteresowania Boga ich osobą. Odczucia badanych miały gwarantować zwiększenie szans na spełnienie próśb przez Boga.

\section{Wzorce życia religijnego młodzieży zagrożonej niedostosowaniem społecznym}

Najważniejszymi wzorcami życia dla dziecka są rodzice. Tak samo jest ze wzorcami życia religijnego. Opisując rodziców jako wzorce życia religijnego, respondenci określali ich jako osoby wierzące-niepraktykujące lub niewierzące, będące przy tym obojętne religijnie. We wspomnieniach badanych, związanych z religią, rodzice kojarzyli im się wyłącznie z przygotowaniami do Pierwszej Komunii Świętej oraz sporządzaniem posiłków na święta religijne. W narracjach badanych pojawiały się pojedyncze osoby z grona dalszej rodziny, które próbowały wpłynąć na rozwój życia religijnego - babcie, ciocie. „Badacz: Kto był wzorem życia religijnego i tego, jak należy postępować? Badany: Moja ciocia, która nie żyje" [fragment wywiadu 4]. Poruszając tematykę wzorców moralnych, respondenci stwierdzili, że są nimi rodzice oraz ich wewnętrzne odczucia. Natomiast nauczanie moralne, wynikające z wyznawanej religii, w większości nie jest znane, a poznane treści są w większości odrzucane.

W środowisku szkolnym wzorcami życia religijnego dla badanych byli wyłącznie katecheci, głównie na etapach edukacji początkowej, kiedy to posiadali oni największy prestiż wśród badanych oraz mieli wpływ na ich życie religijne.

Ostatnim środowiskiem wychowawczym byli rówieśnicy. Badani nie rozmawiali ze znajomymi na tematy związane z religijnością oraz praktyką religijną. „Nie, bo większość moich znajomych nie wierzy" [fragment wywiadu 2]. Tendencja ta również występuje wśród respondentów aktywnie działających w organizacjach religijnych. Według badanych tematyka religijna w środowisku rówieśniczym jest nieatrakcyjna, nudna oraz nie stanowi ważnej części ich życia. 


\section{Zależność pomiędzy wiedzą religijną i moralną młodzieży zagrożonej niedostosowaniem społecznym a klimatem religijnym, jaki panował w domu rodzinnym}

Na podstawie przeprowadzonych wywiadów można ocenić, że poziom wiedzy religijnej i moralnej u badanej młodzieży jest na niskim poziomie. Powyższa ocena stanu wiedzy badanej młodzieży pozwala stwierdzić, że jest ona nieadekwatna do założeń programowych katechezy szkolnej dla danego etapu edukacyjnego. W poniższej tabeli przedstawiono fakty świadczące o niskim poziomie wiedzy religijno-moralnej u badanych oraz przyczyny takiego stanu.

Tabela 2. Wiedza religijna i moralna młodzieży zagrożonej niedostosowaniem społecznym

\begin{tabular}{|l|l|}
\hline \multicolumn{1}{|c|}{$\begin{array}{c}\text { Fakty świadczące o niskim poziomie wiedzy } \\
\text { i kompetencji religijnych }\end{array}$} & \multicolumn{1}{|c|}{ Przyczyny } \\
\hline $\begin{array}{l}\text { Nieznajomość kodeksu moralnego } \\
\text { wyznawanej religii. }\end{array}$ & $\begin{array}{l}\text { Niewłaściwa edukacja religijna w domu oraz } \\
\text { w szkole. Rodzina nie posiada odpowiedniej } \\
\text { wiedzy religijnej, którą może przekazać } \\
\text { dzieciom. Lekcje katechezy nie spełniają } \\
\text { założeń. Lekcje te są tylko spotkaniami } \\
\text { towarzyskimi. }\end{array}$ \\
\hline $\begin{array}{l}\text { Nieprzestrzeganie podstawowych zasad życia } \\
\text { religijnego - nieuczęszczanie na niedzielną } \\
\begin{array}{l}\text { Mszę Świętą. Aktywność religijna związana } \\
\text { z normami społeczno-kulturowymi, a nie } \\
\text { normami religijnymi. }\end{array}\end{array}$ \\
\hline $\begin{array}{l}\text { Brak zdania związanego z nauczaniem } \\
\text { moralnym religii, co się łączy } \\
\text { z nieznajomością treści nauczania moralnego. }\end{array}$ & \\
\hline $\begin{array}{l}\text { Oczekiwanie Boskiej interwencji „tu i teraz” } \\
\text { oraz wystawianie Boga na próbę. }\end{array}$ & \\
\hline $\begin{array}{l}\text { Przedmiotowe traktowanie religii ogranicza- } \\
\text { jące się do korzyści materialnych. }\end{array}$ & $\begin{array}{l}\text { Brak posiadania prawidłowych wzorców życia } \\
\text { w środowisku rodzinnym. }\end{array}$ \\
\hline $\begin{array}{l}\text { Zabawa przedmiotami kultu religijnego } \\
\text { w celach rozrywkowych i „zabicia” nudy. }\end{array}$ & \\
\hline Brak zainteresowania wyznawaną religią. & \\
\hline
\end{tabular}

Źródło: opracowanie własne.

Zestawienie ukazane w tabeli pokazuje nam, że liczne problemy z praktyką religijną łączą się z niewłaściwą edukacją religijną badanych i ich rodziców oraz z brakiem posiadania właściwych wzorców życia religijnego w środowisku rodzinnym.

Rodzinny klimat religijny obowiązujący w domach badanej młodzieży zagrożonej niedostosowaniem społecznym można scharakteryzować w sposób następujący - patrz tabela pierwsza. 
Tabela 3. Religijny klimat rodzinny u badanej młodzieży

Obojętność religijna wynikająca z niepraktykowania religii lub bycia osobą niewierzącą;

Wybiórczość oraz nieregularność praktykach religijnych, która często ograniczała się do zwyczaju społeczno-kulturowego;

Posiadanie przez rodziców i bliskich niskiej oraz niedokładnej wiedzy religijnej, którą następnie przekazują młodszemu pokoleniu;

Celebracja świąt religijnych ograniczająca się wyłącznie do wspólnego posiłku;

Przyzwolenie ze strony rodziców na nieudzielanie się w życiu religijnym.

Źródło: opracowanie własne.

Na podstawie powyższych przykładów można stwierdzić, że wiedza religijno-moralna oraz obowiązujący klimat religijny w domu badanej młodzieży jest w wysokim stopniu powiązany ze sobą. Zarówno życie religijne, jak i wiedza na ten temat badanej młodzieży są lustrzanym odbiciem zasobów religijnych posiadanych przez rodziców.

\section{Religia a pomoc $w$ trudach życia dnia codziennego u młodzieży zagrożonej niedostosowaniem społecznym}

W literaturze teologicznej i psychologicznej mówi się o religii w kontekście pokrzepienia w trudnych sytuacjach życiowych oraz o terapeutycznym charakterze praktyk religijnych. Przebadana młodzież w niewielkim stopniu poszukuje wsparcia i pokrzepienia $\mathrm{w}$ religii oraz u osób duchownych i świeckich związanych z religią. Najczęstszą formą wsparcia religijnego podczas odczuwanego trudu była modlitwa. Praktykowanie modlitwy przez badanych przyczyniało się do:

- poczucia ulgi duchowej - („Fizycznie nie, ale duchowo tak” [fragment wywiadu 2]);

- poczucia wysłuchania swojego problemu - („Badany: Więc czasem, jak mam taką chwilę słabości, to jak jestem w domu sama i nie wiem, coś się tam stało, że płaczę, bądź bardziej ryczę. To się drę, że coś tam, że... czasem mam taki żal do Boga, że nic nie zrobił i coś tam, coś tam. I staram się ochłonąć. I wtedy tak po tym ochłonięciu, staram się pomodlić i coś tam. Porozmawiać. Badacz: Daje Ci to ulgę? Badany: Uhymm" [fragment wywiadu 1]).

Z narracji respondentów wyróżniamy trzy formy pokrzepienia religijnego (patrz: rysunek 1). 


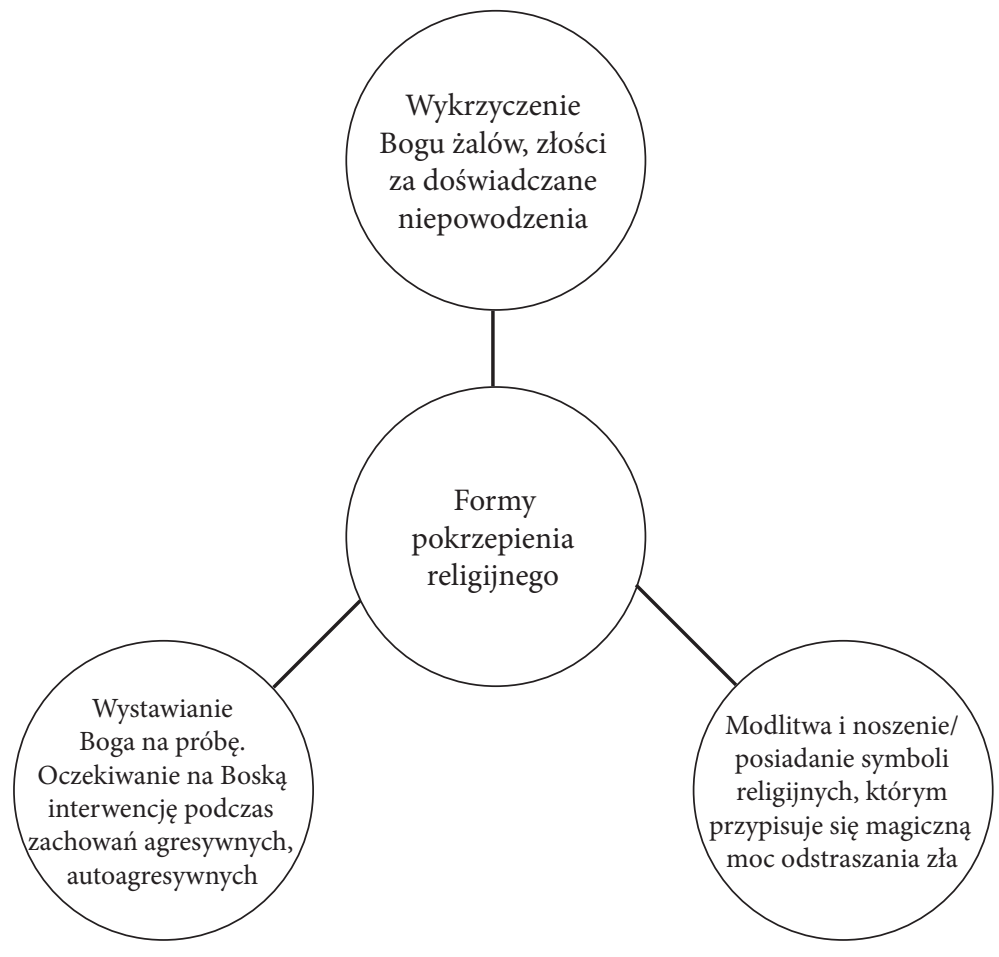

Rysunek 1. Formy pokrzepienia religijnego

Źródło: opracowanie własne.

Badani nie decydowali się na uzyskiwanie pomocy i wsparcia u osób duchownych, bliskich czy też specjalistów. Skłaniali się oni do otrzymania pomocy od osób, które przeżywały podobne problemy.

Uczestnicy badania, posiadając obojętny stosunek religijny przy jednoczesnym odrzuceniu religii w życiu codziennym, paradoksalnie w sytuacjach problemowych odczuwają potrzebę więzi z Bogiem. Narracje badanych świadczą o tym, że trudności życiowe determinują do poszukiwania kontaktu z Bogiem w celu uzyskania pomocy.

\section{Religijne wsparcie procesu socjalizacji i resocjalizacji młodzieży zagrożonej niedostosowaniem społecznym}

Zarówno religia, jak i praktyka religijna uznawane są za nośniki kultury. Poprzez poznawanie kultury i uczestnictwo w życiu kulturalnym uczymy się, w jaki sposób należy funkcjonować w społeczeństwie. Dlatego też można uznać, że duchowość jest sferą kształtującą jednostkę. Narracje badanych ukazują, w jaki sposób w domach rodzinnych zostało im przekazany tradycyjny sposób celebracji świąt religijnych, nie została im natomiast przekazana treść teologiczna związana z przeżywaniem 
świąt. Podobnie jest z Pierwszą Komunią Świętą, gdy pomija się aspekt teologiczny, a skupia się na warstwie materialnej. Dzieci w sposób naturalny i nieintencjonalny uczone są celebracji świąt religijnych ograniczającej się wyłącznie do warstwy kulturowej z pominięciem kontekstu religijnego.

Ważnym kontekstem socjalizacyjnym jest przekazanie młodemu pokoleniu obowiązującego w społeczeństwie kodeksu moralnego. Z narracji badanej młodzieży wynika, że rodzice w swoim życiu codziennym nie odwoływali się do religijnych wartości moralnych. W wyniku procesów socjalizacyjnych i wychowawczych moralność religijna nie była przekazywana badanym.

Religia uznawana jest za czynnik socjalizujący jednostkę. Można ją również uznać za czynnik resocjalizujący. Na podstawie przeprowadzonych badań trudno jest ocenić skuteczność oddziaływań religijnych w procesie resocjalizacji, można jedynie postawić hipotezę, że oddziaływania religijne będą w najmniejszym stopniu determinowały resocjalizację młodzieży. O fakcie niskiej skuteczności oddziaływań religijnych w procesie resocjalizacji mogą świadczyć następujące przesłanki: brak prawidłowych wzorców życia religijnego w środowisku wychowawczym, które wynikają z braku dojrzałości religijnej rodziców oraz zewnętrzne i materialne podejście do religii. Przyczyniły się one do nieprawidłowej stymulacji wychowawczej zorientowanej na rozwój religijny dziecka. Skutkiem takich oddziaływań wychowawczych w późniejszych etapach życia młodych ludzi jest niewłaściwe rozumienie wiary oraz niechęć do praktykowania religii. Dlatego też to, co kiedyś nie było ważnym aspektem życia dla badanego, nie może stać się predyktorem zmian w późniejszych etapach życia.

\section{Dyskusja wyników}

Wyniki uzyskane w ramach badań jakościowych przeprowadzonych na małej próbie osób nie pozwalają na generalizację wyników na całą populację. Jednocześnie przeprowadzona analiza umożliwia stwierdzenie, że przedstawione wyniki wpisują się w opisywane tendencje w literaturze. Ewa Stachowska w swoich badaniach dotyczących religijności młodzieży w krajach europejskich omawia tendencję spadku religijności wśród młodzieży, jak i dystansowania się od religijności instytucjonalnej (Stachowska 2019). Drugą obserwowalną tendencją w religijności młodzieży w skali międzynarodowej jest opisany wcześniej Moralistyczny Deizm Terapeutyczny (patrz: przypis 5). Przedstawione przeze mnie analizy wpisują się w obserwowalne na większą skalę tendencje w życiu religijnym młodzieży.

Ostatnim aspektem mojej analizy materiału badawczego był aspekt wsparcia religijnego w procesie resocjalizacji. Postawiona przeze mnie hipoteza, służąca dalszej analizie, może znaleźć rozwiązanie w badaniach Sylwestera Bębasa, który wykazał, że młodzież jest mało religijna i posiada niewielką wiedzę religijną. Jednocześnie stwierdził, że religia nie jest czynnikiem determinującym i wpływającym na proces resocjalizacji młodzież (Bębas 2015). 


\section{Wnioski}

Na podstawie przeprowadzonych badań dotyczących doświadczeń wychowania religijnego młodzieży zagrożonej niedostosowaniem społecznym można wysnuć następujące wnioski:

1. Badana młodzież posiada obojętny stosunek do religii, przy jednoczesnym reprezentowaniu religijności typu zewnętrznego ${ }^{5}$;

2. Proces wychowania religijnego zachodził w sposób nieregularny, w okresie dziecięcym proces nie istniał. W okresie nauczania początkowego następował zintensyfikowany i bogaty przekaz treści religijnych. Po osiągnięciu szczytu procesu wychowawczego w czasie edukacji początkowej nastapił spadek intensywności procesu wychowawczego zorientowanego na religię. Stąd badani pozostali w stadium rozwoju religijności osiągniętym w okresie dziecięcym, tj. na poziomie religijności magicznej. Badana młodzież nie przejawiała chęci do dalszego rozwoju religijnego;

3. Respondenci nie posiadali odpowiednich wzorców życia religijnego oraz wzorców moralnych związanych z religią;

4. Posiadana przez badaną młodzież wiedza religijna oraz prowadzone przez nią życie religijne jest odzwierciedleniem klimatu życia religijnego obowiązującego w domu;

5. Badana młodzież pomimo niskiego poziomu religijności nie zatraciła wewnętrznej potrzeby uzyskiwania wsparcia religijnego podczas przeżywanych kryzysów;

6. Socjalizacja religijna zorientowana jest wyłącznie na przekaz tradycji rytuałów z pominięciem treści teologicznych. Można jednak wnioskować, że wykorzystywanie treści religijnych $\mathrm{w}$ procesie resocjalizacji badanej młodzieży będzie miało dość znikomy wpływ na dalsze życie.

\section{Bibliografia}

Bergoglio J.M. (2013). Wymagania i pasja - o wychowaniu chrześcijańskim. Kraków: Wydawnictwo Esprit.

Bębas S. (2015). Rola religii w resocjalizacji. Toruń: Wydawnictwo Edukacyjne Akapit.

5 Religijność zewnętrzna - polega na praktykowaniu religii ze względu na wynikające z niej poczucie bezpieczeństwa oraz z powodów społecznych. Osoby reprezentujące ten typ religijności cechują się brakiem zależności pomiędzy deklarowaną religijnością a wyrażanymi postawami w życiu codziennym. Zasady życia religijnego nie są przez takie osoby internalizowane i są wypełniane jedynie z powodu presji społecznej. Osoby te łatwo zmieniają poglądy, traktują Boga jako środek zaspakajający własne potrzeby, a także nie odczuwają potrzeby uczestnictwa w regularnych praktykach religijnych (Dziedzic 2016, s. 67-86). 
Charchut D. (2015). Znaczenie pedagogiki religii w wychowaniu. „Pedagogika Katolicka", nr 17, s. 173-179.

Creswell J.W. (2013). Projektowanie badań naukowych. Metody jakościowe, ilościowe i mieszane. Kraków: Wydawnictwo Uniwersytetu Jagiellońskiego.

Czekaj M. (2015). Doktryna wobec codzienności. Studium fenomenograficzne o wychowaniu religijnym w rodzinie. Kraków: Zakład Wydawniczy „Nomos”.

Dziedzic J. (2016). Religijność, a postawy moralne polskiej młodzieży. „Polonia Sacra", nr 20.

Franciszek (2016). Posynodalna Adhortacja Apostolska „Amoris Laetitia”. O miłości w rodzinie. Dostępny na: http://www.poradnictwo.gda.pl/images/media/ pliki_pdf/AmorisLaetitia.pdf (dostęp 6.09.2019).

Heland-Kurzak K. (2021). Dziecięca kreacja obrazu Boga i religijności - perspektywa pedagogiczna. Warszawa: Wydawnictwo Akademii Pedagogiki Specjalnej.

Konecki K.T. (2000). Studia z metodologii badań jakościowych. Teoria ugruntowana. Warszawa: Wydawnictwo PWN.

Kowalczyk D. (2020). Moralistyczny deizm terapeutyczny. Dostępny na: http:// idziemy.pl/komentarze/moralistyczny-deizm-terapeutyczny (dostęp 25.01.2020).

Kowalik P. (2001). Badania pedagogiczne opierajace się na metodzie biograficznej. „Nauczyciel i Szkoła”, t. 3-4 (12-13), s. 115-121.

Kuczkowski S. (1998). Psychologia religii. Kraków: Wydawnictwo WAM, s. 67-71.

Mastalski J. (2012). Model wychowania w nauczaniu bł. Jana Pawła II. „Verbum Vitae", nr 21, s. 253-271

Matusek B. (2015). Z teorii i praktyki prazy z uczniami zagrożonymi niedostosowaniem społecznym w szkole podstawowej. „Zeszyty Naukowe Humanitas Pedagogika", nr 10, s. 145-157.

Nowak S. (2007). Metodologia badań społecznych. Warszawa: Wydawnictwo PWN.

Okoń W (2001). Nowy słownik pedagogiczny. Warszawa: Wydawnictwo Akademickie Żak.

Okoń W. (2001). Nowy stownikpedagogiczny. Warszawa: Wydawnictwo Akademickie Żak.

Paweł VI (1965). Deklaracja o wychowaniu chrześcijańskim „Gravissimum educationis". Dostępny na: https://opoka.org.pl/biblioteka/W/WP/pawel_vi/inne/ deklaracja_wych_28101965.html (dostęp 16.04.2019).

Pius XI (1932). Divini Illius Magistri - o chrześcijańskim wychowaniu młodzieży. Nakład kancelaryjny Prymasa Polski.

Pytka L. (2005). Pedagogika resocjalizacyjna. Wybrane zagadnienia teoretyczne, diagnostyczne i metodyczne. Warszawa: Wydawnictwo Akademii Pedagogiki Specjalnej.

Rogowski C. (2011). Pedagogika religii: podręcznik akademicki. Toruń: Wydawnictwo Adam Marszałek.

Rubacha K. (2011). Metodologia badań nad edukacją. Warszawa: Oficyna Wydawnicza Łośgraf. 
Skrzypczak R. (2020). Recencja książki Roda Drehera „Opcja Benedykta. Jak przetrwać czas neopogaństwa". Kraków: Wydawnictwo AA.

Słotwińska H. (2016). Pedagogika religii w relacjach $z$ dyscyplinami teologicznymi. Lublin: Wydawnictwo KUL.

Stachowska E. (2019). Religijność młodzieży w Europie - perspektywa socjologiczna. Kontynuacje. „Przegląd religioznawczy”, nr 3 (273).

Stańkowski B. (2015). Jan Paweł II i Benedykt XVI o wychowaniu i duchowym rozwoju młodzieży. „Pedagogika Społeczna”, nr 1.

Śliwerski B. (2015). Współczesne teorie i nurty wychowania. Kraków: Wydawnictwo Impuls.

Urbaniak-Zając D. (2009). O stosowaniu hipotez w badaniach pedagogicznych. „Teraźniejszość-Człowiek-Edukacja: kwartalnik myśli społeczno-pedagogicznej", nr 1 (45), s. 7-27.

\title{
RELIGIOUS UPBRINGING IN BIOGRAPHIES OF YOUNG PEOPLE AT RISK OF SOCIAL MALADJUSTMENT - PRESENTATION OF RESEARCH RESULTS
}

\begin{abstract}
The following paper is a presentation of the results of the research carried out for the Master's thesis. The subject of the study was the religious upbringing of young people at risk of social maladjustment, where the research process was devoted to the diagnosis of the state of religious upbringing and the description of the course of this upbringing. The authors chose the biographical method research with the use of the unstructured interview technique. The conducted research shows that religious upbringing of the examined youth is limited in its manifestations and occurred mainly in the period of early education.
\end{abstract}

Keywords: religious upbringing, upbringing in the teaching of the Catholic Church, religious, youth's at risk of social maladjustment, social rehabilitation. 